\title{
SCREENING OF LACTIC ACID BACTERIA FROM VACUUM PACKAGED BEEF FOR ANTIMICROBIAL ACTIVITY
}

\author{
Roseane B. P. Oliveira ${ }^{1 *}$; Afonso de L. Oliveira ${ }^{2}$; M. Beatriz A. Glória ${ }^{1}$ \\ ${ }^{1}$ Laboratório de Bioquímica de Alimentos, Faculdade de Farmácia, Universidade Federal de Minas Gerais, Belo Horizonte, MG, \\ Brasil; ${ }^{2}$ Departamento de Tecnologia e Inspeção de Produtos de Origem Animal, Escola de Veterinária, Universidade Federal de \\ Minas Gerais, Belo Horizonte, MG, Brasil
}

Submitted: April 04, 2007; Returned to authors for corrections: December 02, 2007; Approved: February 11, 2008.

\begin{abstract}
The objective of this study was to isolate lactic acid bacteria (LAB) from vacuum packaged beef and to investigate their antagonist activity. LAB mean counts of $5.19 \mathrm{log} \mathrm{cfu} / \mathrm{cm}^{2}$ were obtained from five samples of vacuum packaged beef. Two hundred isolates were selected and screened for the inhibitory effect on five ATCC reference Lactobacillus strains. Thirty six isolates showed activity in the agar spot test against at least two of the indicator strains. However, only six cell free supernatants (CFS) from these isolates exhibited activity against the indicator strains using the well-diffusion test and conditions that eliminated the effects of organic acids and hydrogen peroxide. L. acidophilus was the most sensitive indicator tested, whereas $L$. plantarum and $L$. fermentum were the most resistant ones. Identification by MIDI system indicated that these LAB isolates were Lactococcus lactis subsp. cremoris, Pediococcus acidilactici, Lactobacillus delbrueckii subsp. bulgaricus and Lactobacillus casei GC subgroup A. The antagonistic factors produced by most of these LAB against $L$. acidophilus were resistant to heat treatment $\left(100^{\circ} \mathrm{C}\right.$ for $\left.10 \mathrm{~min}\right)$ and stable over a wide $\mathrm{pH}$ range (4.0 to 9.0). These data suggest that these isolates could be used as promising hurdles aiming increased safety and extended shelf life of meat products.
\end{abstract}

Key words: lactic acid bacteria, beef, Lactobacillus, inhibitory activity, $\mathrm{pH}$, heat resistance

\section{INTRODUCTION}

Lactic acid bacteria (LAB) have a long history of safe use in fermented foods. Today, LAB still play an essential role in the majority of food fermentations. One of the most important contributions of these microorganisms is the extended shelf life of fermented products. However, they also have beneficial influence on nutritional and sensory characteristics as well as on the standardization of end products $(2,4,10,18)$.

The growth of spoilage and pathogenic bacteria in food containing LAB is inhibited. This can be due to competition for nutrients and also to $\mathrm{pH}$ reduction by the organic acids produced. Furthermore, these bacteria have the ability to produce a variety of antimicrobial substances as a natural competitive means to overcome other microorganisms sharing the same niche, among them, ethanol, formic acid, acetoin, hydrogen peroxide, diacetyl and bacteriocins. The last ones are small, ribosomally synthesized, peptides or proteins which inhibit microorganisms that are usually closely related to the producer strain. The antibacterial spectrum frequently includes Gram-positive spoilage organisms and food-borne pathogens such as Listeria monocytogenes and Staphylococcus aureus $(1,4,8,10,11,21,22,24)$.

LAB or bactericions have received increased attention during the last few decades. They have been mainly used in food preservation and safety either separately or in combination with other conventional treatment as part of hurdle technology (16). Other applications are now being considered including their use as functional foods (prebiotics, probiotics or nutraceuticals) as well as in human therapy $(1,4,10,22)$. It also

*Corresponding Author. Mailing address: LBqA - Laboratório de Bioquímica de Alimentos, Faculdade de Farmácia, Universidade Federal de Minas Gerais, Av. Antonio Carlos 6627, Belo Horizonte, Minas Gerais, Brasil 30270 901. Fone/fax 55313409 6911. E-mail: roseane_passos@yahoo.es 
satisfies industrial and consumers demands. Some of the trends of the food industry, such as the need to eliminate the use of artificial ingredients and additives, the demands for minimallyprocessed and fresher foods, as well as for ready-to-eat food or the request for functional foods and nutraceuticals could be satisfied $(2,11,24)$.

The meat industry is going through significant technological change, pressured by consumer's demands. The addition of LAB to meat products can improve safety and stability of the products, extending shelf life by inhibiting undesirable changes brought about by spoilage microorganisms or abiotic reactions. It can also provide modifications of the raw material to obtain new sensory properties and health benefits through positive effects on the intestinal microbiota $(5,20,21)$. The identification of LAB that dominate the microbiota of meat is an important step in the search for potential new starter cultures and bacteriocins for meat preservation and fermentation $(4,20)$.

The aim of the present work was: (i) to isolate LAB from vacuum packaged beef; (ii) to evaluate the antagonist effect of LAB on indicator Lactobacillus strains; (iii) to identify LAB with bacteriocinogenic potential; (iv) to evaluate the antagonist effect of CFS on indicator Lactobacillus strains; and (v) to evaluate the effect of $\mathrm{pH}$ and heat treatments on the CFS antagonist activity.

\section{MATERIAL AND METHODS}

\section{Samples, bacterial strains and growth media}

Five samples of vacuum packaged beef (strip loin) from different abattoirs were purchased at different retail markets of Belo Horizonte, MG, Brazil, in a period of three months. Each sample was identified and kept at $4 \pm 1^{\circ} \mathrm{C}$ for a maximum of $24 \mathrm{~h}$ before analysis.

Five ATCC (American Type Culture Collection) reference strains of Lactobacillus were kindly provided by the Department of Microbiology, ICB, UFMG: Lactobacillus acidophilus ATCC 4356; Lactobacillus fermentum - ATCC 9338; Lactobacillus delbrueckii - ATCC 7830; Lactobacillus brevis ATCC 367; and Lactobacillus plantarum - ATCC 8014. They were used as the indicator strains.

All strains (indicator and isolated) were grown in de Man, Rogosa, Sharpe (MRS, Oxoid, Basingstoke, UK) broth or agar $\left(\mathrm{pH} 6.2\right.$ ) at $32^{\circ} \mathrm{C}$. They were routinely propagated and stored at $-20^{\circ} \mathrm{C}$ supplemented with glycerol $(20 \% \mathrm{v} / \mathrm{v})$. Working cultures were sub-cultured twice $\left(1 \%\right.$ inoculum, $\left.24 \mathrm{~h}, 32^{\circ} \mathrm{C}\right)$ prior to use.

\section{Isolation and selection of $L A B$ isolates}

For isolation of the lactic acid bacteria, the vacuum packed beefs were opened aseptically. A $25 \mathrm{~cm}^{2}$ sample of the surface was taken using a sterile cotton swab and homogenized in 10 $\mathrm{mL}$ peptone water $0.1 \% \mathrm{w} / \mathrm{v}$. From the first homogenate, serial decimal dilutions were prepared using the same diluent. Aliquots of $0.1 \mathrm{~mL}$ of the appropriate dilutions were inoculated, using spread plate technique, onto the surface of Petri dishes containing MRS agar, in duplicate. After incubation at $32^{\circ} \mathrm{C}$ for $48 \mathrm{~h}$ under aerobiosis the colonies were counted (8).

Forty colonies of LAB from each sample were selected, which provided a total of $200 \mathrm{LAB}$ isolates from the five beef samples. The selected LAB colonies were grouped according to the morphological characteristics. They were transferred to test tubes with MRS broth containing 20\% glycerol and kept frozen at $-20^{\circ} \mathrm{C}$. They were sub-cultured twice $\left(1 \%\right.$ inoculum, $32^{\circ} \mathrm{C}$ for $24 \mathrm{~h}$ ) in MRS broth prior to use.

\section{Identification of the $\mathrm{LAB}$ isolates}

The selected LAB isolates were characterized by Gram stain, presence of spores and catalase test (8). Gram + , catalase and spores negative strains were maintained frozen until needed for antimicrobial activity testing.

The LAB isolates which had $\mathrm{pH}$ neutralized and CFS with relevant antimicrobial activity against the indicator strains were also identified by gas chromatographic (GC) analysis (Shimadzu, Kyoto, Japan) of fatty acid methyl esters (FAMEs) using a MIDI Sherlock ${ }^{\circledR}$ Microbial Identification System. The fatty acids from the cells were extracted, saponified and esterified to give the respective FAMEs which were analyzed by GC with a flame ionization detector and a phenyl methyl silicone fused silica capillary column as described by Buyer (6).

\section{Inhibition of indicator Lactobacillus strains by the selected LAB isolates}

The inhibitory activity of the selected LAB isolates against the indicator Lactobacillus strains was assayed by the agar spot test described by Schillinger and Lücke (21). The LAB isolates were spotted onto the surface of MRS agar plates and incubated at $32^{\circ} \mathrm{C}$ for $24 \mathrm{~h}$ to allow colonies to develop. The indicator Lactobacillus strains were inoculated into $10 \mathrm{~mL}$ of soft MRS agar $(0.9 \%$ agar) and poured over the plate on which the $\mathrm{LAB}$ isolates were grown. After incubation at $32^{\circ} \mathrm{C}$ for $24-48$ $\mathrm{h}$ under aerobiosis, the plates were examined for the presence of inhibition zones. Inhibition was considered positive when the width of the clear zone around the colonies of the LAB isolates was $0.5 \mathrm{~mm}$ or larger.

\section{Preparation of cell free supernatants}

The strains of the selected LAB isolates which showed inhibition zone for at least two indicator Lactobacillus strains were used for further studies. Cell free supernatants (CFS) from these strains were obtained and their inhibitory activity against the indicator Lactobacillus strains was assayed by the agar well-diffusion test (8).

CFS were obtained from MRS broth cultures after $18 \mathrm{~h}$ incubation at $32^{\circ} \mathrm{C}$ by centrifugation (Jouan Br4i, France) at $10,000 \mathrm{~g}$ for $10 \mathrm{~min}$ at $4^{\circ} \mathrm{C}$. To rule out inhibition due to $\mathrm{pH}$ 
reduction caused by organic acids, the $\mathrm{pH}$ of the supernatants were adjusted to 6.2 using $1 \mathrm{~N} \mathrm{NaOH}$. Inhibitory activity from hydrogen peroxide was also eliminated by addition of catalase (Sigma Chemical Co, St Louis, MO, USA) at $130 \mathrm{U} / \mathrm{mL}$. The supernatants were filter-sterilized through $0.22 \mu \mathrm{m}$ pore-size filters (Schleicher \& Schüll, Dassel, Germany).

\section{Inhibition of indicator Lactobacillus strains by the CFS of selected LAB isolates}

To determine the inhibitory activity of the CFS, plates were made by adding approximately $10^{5} \mathrm{cfu} / \mathrm{mL}$ of an overnight culture of the reference strains to Petri dishes containing MRS agar. Wells ( $6 \mathrm{~mm}$ diameter) were made with a sterile metal cylinder and were filled with $50 \mu \mathrm{L}$ of the $\mathrm{pH}$ neutralized and hydrogen peroxide free, sterile CFS. After diffusion at $4 \pm 1^{\circ} \mathrm{C}$ for $1 \mathrm{~h}$, the plates were incubated at $32^{\circ} \mathrm{C}$ for $24 \mathrm{~h}$. The diameters of the inhibition zones around the wells were measured with a caliper (8).

\section{Influence of heat treatment and $\mathrm{pH}$ on the inhibitory effect of CFS on Lactobacillus acidophilus}

The CFS from the selected LAB isolates were used to determine the influence of heat treatment $\left(60\right.$ and $100^{\circ} \mathrm{C}$, for 10 and $30 \mathrm{~min}$ ) and $\mathrm{pH}$ (4.0 to 9.0) on the inhibitory effect against $L$. acidophilus. The controls were CFS kept under refrigeration and $\mathrm{pH}$ 6.2, respectively. The agar well-diffusion test was used as previously described.

\section{Statistical analysis}

The data from the study of the influence of heat treatment and $\mathrm{pH}$ on the inhibitory effect of CFS on L. acidophilus were submitted to one-way ANOVA and the means were compared by the Newman-Keuls test $(p \leq 0.05)$.

\section{RESULTS}

\section{Isolation and selection of $L A B$}

All the isolates obtained in this study were considered LAB based on their positive Gram reaction, non-motility, absence of catalase activity and of spore formation, and the rod or coccal shape. The counts of LAB from the surface of the vacuum packaged beef samples varied from 4.72 to 5.63 $\log \mathrm{cfu} / \mathrm{cm}^{2}$, with an average of $5.19 \log \mathrm{cfu} / \mathrm{cm}^{2}$. Similar counts were reported by Katikou et al. (14) and Serdengecti et al. (23) for vacuum packaged beef. Forty colonies of LAB from each sample were selected, providing a total of $200 \mathrm{LAB}$ isolates for further studies.

\section{Inhibition of indicator Lactobacillus strains by the selected LAB isolates}

The inhibitory effect of the 200 selected LAB isolates against the indicator Lactobacillus strains were as follows: $28 \%$ of the
LAB isolates inhibited the growth of L. acidophilus; $26 \%$ inhibited L. brevis and L. fermentum; 14\% L. delbrueckii and only $7 \%$ inhibited $L$. plantarum. Based on these results, $L$. acidophilus was the most sensitive, whereas L. plantarum was the least sensitive indicator to the selected LAB isolates from vacuum packaged beef.

Overall, $36 \mathrm{LAB}$ isolates showed inhibitory effect against two indicator Lactobacillus strains (Table 1), which represented $18 \%$ of the 200 previously selected LAB isolates. Interestingly, none of the selected LAB isolates showed inhibitory effect to more than two indicator strains.

\section{Inhibition of indicator Lactobacillus strains by the CFS of selected LAB isolates}

The inhibition of the indicator Lactobacillus strains by the CFS of the LAB isolates determined by the well-diffusion agar test is indicated on Table 2. Only 6 of the $36 \mathrm{LAB}$ isolates (17\%) had CFS with inhibitory effect against the indicator strains investigated. The inhibitory effect observed for the other 30 $\mathrm{LAB}$ isolates when using the agar spot test could be attributed to the production of lactic and acetic acids and the consequent $\mathrm{pH}$ decrease or to the presence of hydrogen peroxide (20). Furthermore, false negative results in the well-diffusion assay for positive results in the agar spot test are possible due to aggregation, non-diffusible bacteriocins, protease inactivation and concentration effects $(5,21)$.

L. acidophilus was observed to be the most sensitive indicator strain to the inhibitory effects of the SFC of the LAB isolates. However $L$. fermentum and $L$. plantarum were the least sensitive.

Only $17 \%$ of the 36 selected LAB isolates ( $3 \%$ of the 200 initial LAB isolates) could have their inhibitory effect against indicator Lactobacillus strains due to bacteriocin like substances or other factors such as $\mathrm{pH}$ and hydrogen peroxide were ruled out. Based on these results, most of the inhibitory effect observed for the LAB isolates was due to $\mathrm{pH}$ or hydrogen peroxide production. Therefore, the ability to produce bacteriocin seems to be scarce among LAB isolates from vacuum packaged beef.

Similar results were described in the literature $(5,9,21)$. Bromberg et al. (5) isolated 813 strains of LAB from meat and meat products and found that only $16 \%$ were bacteriocinproducing strains and $12 \%$ were effective against indicator Lactobacillus species. De Martinis and Freitas (9), evaluating vacuum packaged beef, found only three strains capable of inhibiting Lactobacillus species and Listeria monocytogenes. On the other hand, a higher number of LAB producing inhibitory substances has been found in dairy products and fermented grains $(3,12,15,17,18)$.

MIDI system studies on the identification of the LAB isolates with possible bacteriocinogenic potential indicated that $\mathrm{LAB}$ isolate B was Lactococcus lactis subsp. cremoris. C was 
Table 1. Presence and absence of inhibition of some indicator Lactobacillus strains by selected lactic acid bacteria (LAB) isolates from vacuum packaged beef using the agar spot test

\begin{tabular}{|c|c|c|c|c|c|}
\hline \multirow{2}{*}{ LAB isolate (number) } & \multicolumn{5}{|c|}{ Presence $(+)$ or absence (-) of inhibition of indicator Lactobacillus strains } \\
\hline & L. acidophilus & L. fermentum & L. delbrueckii & L. brevis & L. plantarum \\
\hline 8 & + & - & - & + & - \\
\hline 15 & - & - & + & - & + \\
\hline 16 & + & - & - & + & - \\
\hline 20 & + & - & + & - & - \\
\hline 23 & - & + & + & - & - \\
\hline 25 & - & + & - & + & - \\
\hline 31 & + & - & - & + & - \\
\hline 43 & - & + & - & + & - \\
\hline 44 & + & - & + & - & - \\
\hline 45 & + & - & - & + & - \\
\hline 51 & - & - & + & + & - \\
\hline 54 & - & + & - & - & + \\
\hline 59 & - & + & - & + & - \\
\hline 60 & - & - & - & + & + \\
\hline 85 & - & - & + & + & - \\
\hline 89 & + & - & - & - & + \\
\hline 93 & - & + & - & + & - \\
\hline 105 & - & - & + & + & - \\
\hline 115 & - & + & + & - & - \\
\hline 118 & + & - & + & - & - \\
\hline 130 & + & - & - & + & - \\
\hline 139 & - & + & - & + & - \\
\hline 142 & + & - & + & - & - \\
\hline 148 & + & - & - & + & - \\
\hline 150 & + & - & - & + & - \\
\hline 155 & - & + & - & + & - \\
\hline 156 & - & + & - & - & + \\
\hline 158 & + & + & - & - & - \\
\hline 164 & + & - & + & - & - \\
\hline 169 & - & + & - & + & - \\
\hline 174 & - & + & - & + & - \\
\hline 178 & + & - & - & + & - \\
\hline 182 & - & + & - & + & - \\
\hline 185 & + & - & + & - & - \\
\hline 186 & - & + & - & + & - \\
\hline 193 & + & - & + & - & - \\
\hline
\end{tabular}

Pediococcus acidilactici; D was Lactobacillus delbrueckii subsp bulgaricus; E was Lactobacillus casei GC subgroup A; and $\mathrm{F}$ was Pediococcus acidilactici. The similarity indexes for the isolates varied from 0.701 to 0.424 , which is considered good library comparison. According to the literature, these LAB have been reported within the microbiota of beef and other meat products $(13,19)$. Furthermore, these LAB have been described as bacteriocin producers $(1,2,5,8,19)$.

\section{Influence of heat treatment on the inhibitory effect of CFS on Lactobacillus acidophilus}

The influence of heat treatment on the inhibitory effect of CFS on the indicator L. acidophilus is described on table 3. $L$. acidophilus was selected as it was the most sensitive strain by the agar spot test. Overall, the inhibitory compounds present in the CFS were resistant to heat treatment. CFS from LAB isolates $\mathrm{C}$ and D were stable (ca. $72 \%$ activity) when heated at $100^{\circ} \mathrm{C}$ for 
10 min. However CFS from LAB isolates $\mathrm{E}$ and $\mathrm{F}$ were even more heat resistant, keeping 76 to $82 \%$ of the original activity when heated at $100^{\circ} \mathrm{C}$ for $30 \mathrm{~min}$. Interestingly, the inhibiting substances from the different strains of Pediococcus acidilactici (LAB isolates $\mathrm{C}$ and $\mathrm{F}$ ) showed different resistance to heat treatment. This result suggests that heat resistance is strain specific rather than species specific. These results are in agreement to literature reports $(5,7,17,21)$.

Table 2. Diameter of the inhibition zone of indicator Lactobacillus strains by the cell free supernatant (CFS) of selected lactic acid bacteria (LAB) isolates from vacuum packaged beef using the agar well-diffusion test

\begin{tabular}{ccccccc}
\hline $\begin{array}{c}\text { Indicator } \\
\text { Lactobacillus } \\
\text { strain }\end{array}$ & \multicolumn{5}{c}{$\begin{array}{c}\text { Diameter of inhibition zone } \\
(\mathrm{mm}) / C F S * \text { of LAB isolates }\end{array}$} \\
\cline { 2 - 7 } & A & B & C & D & E & F \\
\hline L. acidophilus & - & - & 11.5 & 8.3 & 9.6 & 10.1 \\
L. fermentum & 14.3 & - & - & - & - & - \\
L. delbrueckii & 10.5 & 8.4 & - & 9.7 & - & - \\
L. brevis & - & 12.7 & - & - & 11.2 & 10.9 \\
L. plantarum & - & - & 9.5 & - & - & - \\
\hline
\end{tabular}

- = no inhibition zone; * pH neutralized (6.2) and hydrogen peroxide free; Corresponding to $\mathrm{LAB}$ isolates: $\mathrm{A}=23 ; \mathrm{B}=51 ; \mathrm{C}=89 ; \mathrm{D}=118$; $\mathrm{E}=150 ; \mathrm{F}=178$ (Table 2).

Table 3. Influence of heat treatment on the inhibitory activity of the cell free supernatants (CFS) of selected lactic acid bacteria (LAB) isolates from vacuum packaged beef against $L$. acidophilus using the agar well-diffusion test

\begin{tabular}{ccccc}
\hline $\begin{array}{c}\text { Temperature } \\
\text { / Time }\end{array}$ & \multicolumn{4}{c}{$\begin{array}{c}\text { Diameter of inhibition zone } \\
(\mathrm{mm}) / C S F\end{array}$ from selected LAB isolates } \\
\cline { 2 - 5 } & $\mathrm{C}$ & $\mathrm{D}$ & $\mathrm{E}$ & $\mathrm{F}$ \\
\hline Control & $9.5 \pm 0.4^{\mathrm{a}}$ & $9.0 \pm 0.8^{\mathrm{a}}$ & $11.0 \pm 0.8^{\mathrm{a}}$ & $11.5 \pm 0.4^{\mathrm{a}}$ \\
$60^{\circ} \mathrm{C}$ & & & & \\
$10 \mathrm{~min}$ & $9.1 \pm 0.5^{\mathrm{b}}$ & $8.9 \pm 0.7^{\mathrm{a}}$ & $10.4 \pm 0.6^{\mathrm{a}}$ & $11.2 \pm 0.8^{\mathrm{ab}}$ \\
$30 \mathrm{~min}$ & $7.1 \pm 0.3^{\mathrm{c}}$ & $9.0 \pm 0.8^{\mathrm{a}}$ & $11.0 \pm 1.0^{\mathrm{a}}$ & $10.7 \pm 0.5^{\mathrm{b}}$ \\
$100^{\circ} \mathrm{C}$ & & & & \\
$10 \mathrm{~min}$ & $6.7 \pm 0.3^{\mathrm{d}}$ & $6.7 \pm 0.3^{\mathrm{b}}$ & $9.6 \pm 0.6^{\mathrm{b}}$ & $10.0 \pm 0.8^{\mathrm{c}}$ \\
$30 \mathrm{~min}$ & - & - & $8.4 \pm 0.4^{\mathrm{c}}$ & $9.4 \pm 0.5^{\mathrm{d}}$ \\
\hline
\end{tabular}

$\mathrm{n}=9$ (triplicate in three independent experiments); - = no inhibition zone; Mean values ( \pm standard deviation) with different letters in the same column are significantly different (Newman-Keuls test, $\mathrm{p} \leq 0.05$ ); MIDI identification of LAB isolates: $\mathrm{C}$ and $\mathrm{F}=$ Pediococcus acidilactici; $\mathrm{D}=$ Lactobacillus delbrueckii subsp. bulgaricus; $\mathrm{E}=$ Lactobacillus casei GC subgroup A.

\section{Influence of pH on the inhibitory effect of CFS on Lactobacillus acidophilus}

The influence of the $\mathrm{pH}$ on the inhibitory effect of CFS on the indicator L. acidophilus is described on table 4. The CFS from LAB D (Lactobacillus delbrueckii subsp. bulgaricus) was the most sensitive to $\mathrm{pH}$. At $\mathrm{pH} 5.0$ and 6.0 there was 9 and $18 \%$ loss of activity, respectively, compared to the activity at $\mathrm{pH}$ 4.0. However, at $\mathrm{pH} 7.0$, there was no activity. The different strains of $P$. acidilactici showed similar response to the change in $\mathrm{pH}$. In general, the lower the $\mathrm{pH}$, the higher the inhibitory effect of the CFS on L. acidophilus, however at different rates. Based on these results, it is possible that the low $\mathrm{pH}$ of the CFS might have exerted a combined antimicrobial effect with the bacteriocins or the inhibitory substances present. A reduction in $\mathrm{pH}$ has been previously reported as a mechanism for inhibiting food-borne pathogens (1).

Table 4. Influence of the $\mathrm{pH}$ on the inhibitory activity of the cell free supernatants (CFS) of selected lactic acid bacteria (LAB) isolates from vacuum packaged beef against $L$. acidophilus using the agar well-diffusion test

\begin{tabular}{|c|c|c|c|c|}
\hline \multirow[t]{2}{*}{$\mathrm{pH}$} & \multicolumn{4}{|c|}{$\begin{array}{c}\text { Diameter of inhibition zone } \\
(\mathrm{mm}) / \mathrm{CFS} \text { from selected LAB isolates }\end{array}$} \\
\hline & $\mathrm{C}$ & $\mathrm{D}$ & E & $\mathrm{F}$ \\
\hline 4.0 & $10.1 \pm 0.7^{\mathrm{a}}$ & $11.0 \pm 0.7^{\mathrm{a}}$ & $11.3 \pm 0.6^{\mathrm{a}}$ & $12.5 \pm 0.7^{\mathrm{a}}$ \\
\hline 5.0 & $9.8 \pm 1.2^{\mathrm{ab}}$ & $10.0 \pm 1.2^{\mathrm{b}}$ & $11.2 \pm 0.7^{\mathrm{a}}$ & $12.0 \pm 1.5^{\mathrm{a}}$ \\
\hline 6.0 & $9.5 \pm 1.1^{\mathrm{ab}}$ & $9.0 \pm 0.7^{\mathrm{c}}$ & $11.0 \pm 1.0^{\mathrm{a}}$ & $11.5 \pm 0.8^{a}$ \\
\hline 7.0 & $9.2 \pm 0.9^{\mathrm{ab}}$ & - & $9.9 \pm 1.0^{\mathrm{b}}$ & $10.3 \pm 1.2^{b}$ \\
\hline 8.0 & $8.9 \pm 0.7^{b}$ & - & $8.3 \pm 0.7^{\mathrm{c}}$ & $8.6 \pm 0.4^{c}$ \\
\hline 9.0 & $6.7 \pm 0.3^{c}$ & - & $6.6 \pm 0.2^{\mathrm{d}}$ & $6.9 \pm 0.4^{\mathrm{d}}$ \\
\hline
\end{tabular}

$\mathrm{n}=9$ (triplicate in three independent experiments); - = no inhibition zone; Mean values ( \pm standard deviation) with different letters in the same column are significantly different (Newman-Keuls test, $\mathrm{p} \leq 0.05$ ); MIDI identification of LAB isolates: $\mathrm{C}$ and $\mathrm{F}=$ Pediococcus acidilactici; $\mathrm{D}=$ Lactobacillus delbrueckii subsp. bulgaricus; $\mathrm{E}=$ Lactobacillus casei GC subgroup A.

\section{DISCUSSION}

LAB isolated from meat and meat products are probably the best candidates for improving the microbiological safety of these foods, because they are well adapted to the conditions in meats and should, therefore, be more competitive than LAB from other sources (21). The antagonistic activity of $200 \mathrm{LAB}$ isolates from vacuum packaged beef was investigated.

Despite the high numbers of LAB strains isolated, only 36 $(18 \%)$ showed inhibitory effect on two of the indicator Lactobacillus strains. Furthermore, only $6(3 \%)$ had CFS capable 
of inhibiting the indicator strains. Therefore, these results reflect the low frequency of LAB producing inhibitory substances from vacuum packaged beef.

The LAB identified in this study have been reported to produce bacteriocins. Therefore, it is likely that bacteriocins are responsible for the antagonists effects observed for the CFS. Further purification, identification and technological application should be pursued, in order to propose potential uses as natural preservatives.

The ability of the CFS obtained to show antimicrobial activity in a wide $\mathrm{pH}$ range and after heat treatment is a desirable characteristic for meat and other food applications. Messens \& De Vuyst (17) reported that many LAB and bacteriocins display greater antibacterial activity at lower $\mathrm{pH}$ values ( $\mathrm{pH} 5$ and below). In this study, three CFS showed significant activity up to $\mathrm{pH} 9$. These results are interesting for some meat applications, because some ready to eat meat products, like frankfurters, have high $\mathrm{pH}$. Also, L. monocytogenes generally has a neutral $\mathrm{pH}$ requirement for growth $(4,5)$. Furthermore, the high heat resistance observed is a remarkable property to be used for biopreservation, because many food-processing procedures involve a heating step.

Since some Lactobacillus species can be responsible for spoilage in non fermented meat products, the LAB isolates and their antagonist products could be useful for biopreservation. They can be used as part of or adjuncts to starter cultures for fermented foods in order to improve safety and quality. They can also be used more specifically to selectively inhibit certain high-risk bacteria in foods like $L$. monocytogenes without affecting the harmless microbiota. Therefore, they could act as barrier to inhibit food spoilage and/or growth of pathogenic microorganisms in foods. Furthermore, due to synergistic properties, their use in the food industry can help reduce the addition of chemical preservatives as well as the intensity of heat treatments, resulting in foods which are more naturally preserved and richer in sensory and nutritional properties. This can be an alternative to satisfy the increasing consumer's demands for safe, fresh-tasting, ready-to-eat, minimallyprocessed foods and also to develop "novel" food products. Further work to evaluate the applicability of these substances in biopreservation techniques for meats is in progress.

\section{ACKNOWLEDGEMENT}

The authors thank Fapemig and $\mathrm{CNPq}$ for the financial support.

\section{RESUMO}

\section{Avaliação de bactérias láticas de carne bovina embalada a vácuo quanto à atividade antimicrobiana}

Este trabalho teve como objetivo isolar bactérias ácido láticas (BAL) de carne bovina embalada a vácuo e investigar sua atividade antimicrobiana. Uma média de 5,19 log ufc $/ \mathrm{cm}^{2}$ BAL foi obtida de cinco amostras. Duzentos isolados foram selecionados e o efeito inibitório sobre cinco cepas ATCC referência de Lactobacillus foi pesquisado. Trinta e seis isolados apresentaram atividade inibitória pelo teste 'agar spot' de pelo menos duas das cepas indicadoras. Sobrenadantes isentos de células (SIC) destes isolados foram obtidos. Apenas seis SIC apresentaram atividade contra as cepas indicadoras usando o método de difusão em poços e condições que eliminaram a influência do peróxido de hidrogênio e de ácidos orgânicos. $L$. acidophilus foi a cepa indicadora mais sensível, enquanto $L$. plantarum e L. fermentum foram as mais resistentes. Identificação pelo sistema MIDI indicaram que as BAL isoladas eram Lactococcus lactis subsp. cremoris, Pediococcus acidilactici, Lactobacillus delbrueckii subsp. bulgaricus e Lactobacillus casei GC subgrupo A. O efeito antagonista ao $L$. acidophilus dos SIC destas BAL foi resistente ao tratamento térmico $\left(100^{\circ} \mathrm{C} / 10 \mathrm{~min}\right)$ e estável em ampla faixa de $\mathrm{pH}(4,0 \mathrm{a} 9,0)$. Estes dados sugerem que os isolados obtidos poderiam ser utilizados como barreiras promissoras no aumento da segurança e na extensão da vida útil de produtos cárneos.

Palavras-chave: bactéria lática, carne bovina, Lactobacillus, atividade antimicrobiana, $\mathrm{pH}$, termo resistência

\section{REFERENCES}

1. Allende, A.; Martinez, B.; Selma, V.; Gil, M.I.; Suárez, J.E.; Rodríguez, A. (2007). Growth and bacteriocin production by lactic acid bacteria in vegetable broth and their effectiveness at reducing Listeria monocytogenes in vitro and in fresh-cut lettuce. Food Microbiol., 24, 759-766.

2. Bagenda, D.K.; Yamazaki, K. (2007). Application of bacteriocins in food preservation and safety. Food, 1, 137-148.

3. Batdorj, B.; Dalgalarrondo, M.; Choiset, Y.; Pedroche, J.; Métro, F.; Prévost,H.; Chober, J.M.; Haertlé, T. (2006). Purification and characterization of two bacteriocins produced by lactic acid bacteria isolated from Mongolian airag. J. Appl. Microbiol., 101, 837-848.

4. Benkerroum, N.; Ghouati, Y.; Ghalfi, H. (2007). Screning for bacteriocin-producing lactic acid bacteria from various Moroccan food products and partial characterization of putative bacteriocins. Biotechnol., 6, 481-488.

5. Bromberg, R.; Moreno, I.; Zaganini, C.L.; Delboni, R.R.; Oliveira, J. (2004). Isolation of bacteriocin-producing lactic acid bacteria from meat and meat products and its spectrum of inhibitory activity. Braz. J. Microbiol., 35, 137-144.

6. Buyer, J.S. (2002). Rapid sample processing and fast gas chromatography for identification of bacteria by fatty acid analysis J. Microbiol. Met., 51, 209-215.

7. Carvalho, A.A.T.; Paula, R.A.; Mantovani, H.C.; Moraes, C.A. (2006) Inhibition of Listeria monocytogenes by a lactic acid bacterium isolated from Italian salami. Food Microbiol., 23, 213-219.

8. Cintas, L.M.; Casaus, P.; Fernandez, M.F.; Hernandez, P.E. (1998). Comparative antimicrobial activity of enterocin L50, pediocin PA1, nisin $\mathrm{A}$ and lactocin $\mathrm{S}$ against spoilage and foodborne pathogenic bacteria. Food Microbiol., 15, 289-298.

9. De Martinis E.C.P.; Freitas, F.Z. (2003). Screening of lactic acid bacteria from Brazilian meats for bacteriocin formation. Food Control, 14, 197-200. 
10. De Vuyst, L.; Leroy, F. (2007). Bacteriocins from lactic acid bacteria: production, purification, and food applications. J. Mol. Microbiol. Biotechnol., 13, 194-199.

11. Gálvez, A.; Abriouel, H.; López, R.L.; Omar, N.B. (2007). Bacteriocinbased strategies for food biopreservation. Int. J. Food Microbiol., $120,51-70$.

12. Hernandez, D.; Cardell, E.; Zarate, V. (2005). Antimicrobial activity of lactic acid bacteria isolated from Tenerife cheese: initial characterization of plantaricin TF711, a bacteriocin-like substance produced by Lactobacillus plantarum TF71. J. Appl. Microbiol., 99, 77-84.

13. Jones, R.J. (2004). Observations on the succession dynamics of lactic acid bacteria populations in chill-stored vacuum-packaged beef. Int. J. Food Microbiol., 90, 273-282.

14. Katikou, P.; Ambrosiadis, I.; Georgantelis, D.; Koidis, P.; Georgakis, S.A. (2005). Effect of Lactobacillus-protective cultures with bacteriocinlike inhibitory substances' producing ability on microbiological, chemical and sensory changes during storage of refrigerated vacuum-packaged sliced beef. J. Appl. Microbiol., 99, 1303-1313.

15. Kucerova, K.; Chumchalová, J.; Miková, K.; Cupáková, S.; Karpisková, R.; Ho, L. (2007). Screening of lactic acid bacteria for antimicrobial properties from mayonnaise-based products and raw materials. Eur. Food Res. Technol., 226, 265-272.

16. Leistner, L. (1992). Food preservation by combined methods. Food Res. Int., 25, 151-158.

17. Messens,W.; De Vuyst, L. (2002). Inhibitory substances produced by Lactobacilli isolated from sourdoughs-a review. Int. J. Food Microbiol., 72, 31-43.
18. Omar, N.B.; Abriouel, H.; Lucas, R.; Martínez-Cañamero, M.; Guyot, J.; Gálvez, A. (2006). Isolation of bacteriocinogenic Lactobacillus plantarum strains from ben saalga, a traditional fermented gruel from Burkina Faso. Int. J. Food Microbiol., 112, 44-50.

19. Sakala, R.M.; Hayashidani, H.; Kato, Y.; Hirata, T.; Makino, Y.; Fukushima, A.; Yamada, T.; Kaneuchi, C.; Ogawa, M. (2002). Change in the composition of the microflora on vacuum-packaged beef during chiller storage. Int. J. Food Microbiol., 74, 87-99.

20. Sawitzki, M.C.; Fiorentini, Â.M.; Brod, F.C.A.; Tagliari, C.; Bertol, T.M.; Arisi, A.C.M.; Sant'Anna, E.S. (2007). Phenotypic characterization and species-specific PCR of promising starter culture strains of Lactobacillus plantarum isolated from naturally fermented sausages. Braz. J. Microbiol., 38, 547-552.

21. Schillinger, U.; Lücke, F. (1989). Antibacterial activity of Lactobacillus sake isolated from meat. Appl. Environm. Microbiol., 55: 1901-1906.

22. Schobitz, R.P.; Bórquez, P.A.; Costa, M.E.; Ciampi, L.R.; Brito, C.S. (2006). Bacteriocin like substance production by Carnobacterium psicola in a continuous system with three culture broths. Study of antagonism against Listeria monocytogenes on vacuum packaged salmon. Braz. J. Microbiol., 37, 52-57.

23. Serdengecti, N.; Ibrahim, Y.; Gokoglu, N. (2006). Effects of sodium lactate, sodium acetate and sodium diacetate on microbiological quality of vacuum-packed beef during refrigerated storage. J. Food Saf., 2, 62-71.

24. Stiles, M.E. (1996). Biopreservation by lactic acid bacteria. Antonie Van Leeuwenhoek, 70, 331-345. 